\title{
Pyospermia in Men Seeking Assisted Reproduction Technology
}

\author{
Abayomi B. Ajayi', Bamgboye M. Afolabi ${ }^{2 *}$, Victor D. Ajayi', Ifeoluwa O. Oyetunji', \\ Oluwafunmilola R. Biobaku1, Adedamilola Atiba', Joy Ehichioya1, Ibukun Ayelehin'1, \\ Ayodeji Adeoye ${ }^{1}$, Temilade Adesida ${ }^{1}$ \\ ${ }^{1}$ Nordica Fertility Center, Lagos, Nigeria \\ ${ }^{2}$ Health, Environment and Development Foundation, Lagos, Nigeria \\ Email: ^bmafolabi@gmail.com
}

How to cite this paper: Ajayi, A.B., Afolabi, B.M., Ajayi, V.D., Oyetunji, I.O., Biobaku, O.R., Atiba, A., Ehichioya, J., Ayelehin, I., Adeoye, A. and Adesida, T. (2018) Pyospermia in Men Seeking Assisted Reproduction Technology. Open Journal of Urology, 8, 93-107.

https://doi.org/10.4236/oju.2018.84011

Received: February 22, 2018

Accepted: April 17, 2018

Published: April 20, 2018

Copyright $\odot 2018$ by authors and Scientific Research Publishing Inc. This work is licensed under the Creative Commons Attribution International License (CC BY 4.0).

http://creativecommons.org/licenses/by/4.0/

(C) (i) Open Access

\begin{abstract}
Introduction: Pyospermia is often detected in semen, especially when investigating for male infertility. Pyospermia, in a significantly large number is often correlated with inferior sperm parameters and reduced fertility. Pyospermia may be a factor of a fundamental genitourinary infection. This study assessed the relationship between pus cells and semen parameters in infertile Nigerian males. Subjects and Methods: A cross-sectional descriptive study was carried out at Nordica Fertility Center, Lagos, Nigeria, from 2004 to 2009. A total of 907 subjects were analyzed. Subjects ages (years) were categorized into $\leq 30$, $30.1-35,35.1-40,40.1-45,45.1-50$ and $>50$, BMI into $<18.5$ (underweight), 18.5-24.5 (normal), 25.0 - 29.9 (overweight) and $\geq 30$ (obese) and pus cells into none, $1-2$ and $\geq 3$. Results: Leucocytopenia of $\geq 3$ per high power field (/hpf) occurred in $67(7.4 \%)$ men. The overall means $( \pm$ sd) of pus cells was $1.4(0.9), 1.4(0.7), 1.4(0.7)$ and $1.6(1.6)$ per high power field in all, normospermia, oligoospermic and azoospermic clusters of patients respectively. Mean ( \pm sd) pus cells in semen was $6.0(4.0)$, the highest, among obese $(B M I \geq 30)$ azoospermic patients. The proportion of subjects with pyospermia of 1 - 2 was highest $(323 / 346,93.3 \%)$ among oligoospermic patients while that with pyospermia of $\geq 3$ was highest $(10 / 109,9.2 \%)$ among azoospermic patients. Obese azoospermic patients were 1.8 times as likely to have $\geq 3 / \mathrm{hpf}$ pyospermia compared to normal normospermic patients $\left(x^{2}=0.05, P\right.$-value $=$ $0.51, \mathrm{OR}=1.82,95 \%$ CI: $0.30,11.02)$. Mean progressive motility (\%) was significantly reduced $(\mathrm{t}=1.95, P$-value $=0.03)$ among patients with $\geq 3 / \mathrm{hpf}$ pyospermia $(33.75 \pm 19.23)$ compared to those with $1-2 / \mathrm{hpf}$ pyospermia $(38.58 \pm 21.63)$. Patients with sperm oval head $\leq 30 \%$ had significantly higher pyospermia $(\mathrm{t}=2.22, P$-value $=0.013)$ than those with sperm oval head of $>30 \%$. Conclusion: Elevated pus cell counts were observed among obese
\end{abstract}


azoospermic men, those with reduced sperm progressive motility and those with lower count of sperms with oval head morphology. Clinicians should consider pyospermia relative to body mass index and mean progressive motility in their management of male infertility.

\section{Keywords}

Pyospermia, Male Infertility, Progressive Motility, Oval Head, Nigeria

\section{Introduction}

The dilemma of infertility is not only a medical but also a socio-cultural problem in most societies [1]. Especially in developing countries, the consequences of being infertile could be violence [2] [3] [4], economic adversity, social seclusion and denial of proper death rites [5]. Further, fertility incapacity often results in social ostracization or divorce and may have other consequences such as mental derangement, adverse pregnancy outcomes and other health implications [6] [7] [8] [9]. Studies have associated infertility with high-risk sexual behaviors [3] [4]. In most sub-Saharan families, there is dependence on own-children for not only economic survival but also care, especially in old age [10]. According to a report, the World Health Organization definition of infertility, based on 24 months of trying to get pregnant, may be recommended as useful in clinical practice and research [11]. However, as in most cases, infertility is approached from the perspective of a woman not being able to get pregnant and not from the perspective of a man not being able to get a woman pregnant. For example, studies reported that women are commonly blamed for infertility [12] [13]. Yet male factor infertility accounts for approximately $50 \%$ of all cases of infertility [14] [15] and majority of affected men gave a history of contacting sexually transmitted infections of the genital tract [15] [16]. Pyospermia, (also known as leukospermia or leukocytospermia is defined as the presence of more than $1 \times 10^{6}$ leucocytes (white blood cells) in the ejaculate [16]. The white blood cells are produced by the body's immune system to fight off invading organisms that cause infection but when leucocytes count is elevated in semen, male fertility can be compromised due to increase in oxidative stress and decrease in sperm quality. Askienazy-Elbhar [16] also reported that infections or inflammation of the urethra and prostatitis (inflammation of the prostate gland) are the principal causes of pyospermia, which are mostly asymptomatic, and which are detected after performing seminal fluid analysis as part of male infertility work-up or when a man is screened before becoming a sperm donor. Micro-organisms that have been detected as causative agents in male genital tract infection include Escherichia coli or E. coli, Klebsiella pneumonia, Ureaplasma urealyticum, Proteus mirabilis, Pseudomonas aeruginosa, Staphylococcus aureus, Mycoplasma hominis, Enterococcus faecalis, Morganella morganii and Chlamydia trachomatis and other sexually transmitted diseases (STDs) respectively [16]. It is note- 
worthy that some studies have linked pyospermia with sperm DNA fragmentation in infertile men [17] [18] [19], though the role which pyospermia plays in ICSI and conventional IVF is not yet certain. There exist other causes that can lead to an increased level of leukocytes in the semen. Various studies have revealed that sexual abstinence can have an influence, as the more time sperms remain in the epididymis, the greater the number of macrophages and granulocytes that will be attracted by older sperm, which can cause an elevated level of leukocytes in the ejaculate. Few studies in sub-Saharan Africa have delved into the issue of pyospermia and male infertility. Enwuru et al., [20] reported that normozoospermic males with pyospermia had lower sperm concentration compared with those without contamination, while Onemu and Ibeh [21] concluded that pathogenic pyospermia, consequent upon breach in the integrity of the blood-testes barrier, may provide early warning signals of impairment of male fertility. However, these studies looked at pyospermia mainly from icrobiologyic perspective and did not fully relate pyospermia to age group, body mass index, progressive motility, and normal sperm morphology consisting of sperms with oval heads. The objective of this study, therefore, is to report the association of pyospermia with different age group categories, different BMI categories, different motility categories and different concentrations of normal sperm cell morphology among infertile men presenting for assisted reproduction technology in Nigeria.

\section{Subjects and Methods}

This study was approved by the State Ethics Committee. Data was from patients who consulted at Nordica fertility Center in Lagos from 2004 to 2009. Subjects ages (years) were categorized into $\leq 30,30.1$ - 35, 35.1 - 40, 40.1 - 45, 45.1 - 50 and $>50$, BMI into $<18.5$ (underweight), 18.5 - 24.5 (normal), 25.0 - 29.9 (overweight) and $\geq 30$ (obese) and pus cells into none, 1 - 2 and $\geq 3$, extracted from medical records who presented because of infertility at three Nigerian cities-Lagos, Asaba and Abuja were retrieved, entered into a laptop computer, cleaned and analyzed. Semen samples were obtained by masturbation and collected in a sterile, nontoxic plastic wide-mouth container. The sample was transported to the clinical laboratory within a maximum of 3 - 5 minutes' walk to according to WHO guidelines [22]. The patient was counseled to abstain from sex for minimum/maximum duration of 2 - 5 days and importance of abstinence time was explained. Patients were given clear and simple instructions on the following: 1) accuracy in the semen collection, 2) semen should be collected in a wide-mouth measuring cylinder that was provided, and 3) the importance of reporting any loss of semen sample during collection. For this semen collection process, each patient was provided with a medical record form where data such as name, age (or date of birth), days of abstinence, date and time of collection, if there was any loss in semen volume during collection (incomplete collection) and the time of commencement of seminal fluid analysis in the laboratory were appropriately filled in by the patient and the laboratory staff who collected the 
semen sample. Other anthropometric, social and medical/surgical records were also collected from the patients. These included weight (in $\mathrm{kg}$ ) and height (in $\mathrm{cm}$ ) for the determination of body mass index (BMI), marital status, occupation, smoking and alcohol use, groin operation, sexually transmitted diseases, as well as family and social history. Within 30 minutes of production and collection at the laboratory and after liquefaction, semen samples were analyzed strictly according to WHO guidelines [22] to detect the following semen parameter: volume, total sperm concentration, motility, and morphology. The volume of the ejaculate was measured by directly reading it on a wide-mouth measuring cylinder provided for each patient. A volume of $3-5 \mu \mathrm{L}$ of semen sample was transferred to the center of the chamber; mean progressive motility was determined using light microscope $(\times 40)$ and was performed in 10 squares of the chamber, counting at least 200 spermatozoa and expressed as $10^{6}$ spermato$\mathrm{zoa} / \mathrm{ml}$. The total sperm count is the end concentration, expressed as $10^{6}$ spermatozoa/ml. The sperm motility was assessed in about 100 random spermatozoa as 1) rapidly forward, fast progressive motility, 2) moderately forward, slow progressive motility, 3) jerky non-progressive motility, and 4) immotile/no movement. Other parameters assessed in the semen samples were color, viscosity, liquefaction time, pus cells per high power field and morphology. Patients who were not on any medication that would interfere with spermatogenesis, those not consuming herbal medication and who gave consent for their semen to be analyzed were included into the study. Non-indigenes, those with history of fulminant infections or patients with neoplasm were excluded from the study. Patients' confidentiality was assured by excluding any information such as age, address which could identify any patient with the study.

For the purpose of this study pyospermia was taken as pus cells $\geq 3 / \mathrm{hpf}$ as a certain amount of pus cells is expected in the sperm though detection of bacteria in semen may be an early warning sign of microbe-induced male infertility [21]. Oval heads sperm morphology was categorized into $\leq 30 \%$ and $>30 \%$ respectively.

Data were also coded and stored in a computer with password known only to the Principal Investigator. Data were analyzed using STATA 13; associations between Age, BMI and Age-for-BMI with normal sperm concentration and with azoospermia were assessed using chi-square, Odds Ratio and 95\% Confidence Interval. Spearman correlation and analysis of variance (ANOVA), and a multiple linear regression analysis was performed to determine correlation coefficients and significance of means of two variables. In addition, the relative risks for men having azoospermia, giving reference range of the WHO [23], were calculated. A $P$-value of $\leq 0.05$ was taken as significant. Data were presented as Tables and bar charts.

\section{Results}

\subsection{All Patients}

A total of 907 men, whose means ( \pm sd) of age, body mass index (BMI) and pro- 
gressive motility were $42.7(7.1)$ years and $27.1(3.9) \mathrm{kg} / \mathrm{m}^{2}$ and $38.2(21.5)$ percent respectively, presented infertility. Their ages, BMI and progressive motility ranged from 23 to 73 years, 18.9 to $70 \mathrm{~kg} / \mathrm{m}^{2}$ and from $0 \%-90 \%$ respectively. The proportion that were aged 30 years and younger was the least $(13,1.4 \%)$ while those aged 35.1 to 40 years were in the highest proportion (25.7\%). Majority of the men $(468,51.6 \%)$ were overweight while lower proportions were either normal weight $(268,29.6 \%)$ or obese $(171,18.8 \%)$. Further, a high proportion had progressive motion $\geq 32 \%(606,66.8 \%)$. In all $683(75.3 \%)$ patients had sperms that have $>30 \%$ oval head (normal morphology) and $224(24.7 \%)$ had sperms having $\leq 30 \%$ oval heads. The overall mean $( \pm$ sd) pus cells/hpf was 1.4 (0.9). Most $(839,92.5 \%)$ of the men had pus cells of $1-2 /$ hpf in their seminal fluid and only 67 (7.4\%) had pyospermia of $\geq 3 / \mathrm{hpf}$. The mean pus cells in seminal fluid of normal weight men $(1.5 \pm 0.8)$ /hpf was significantly higher than that among overweight $(1.4 \pm 0.8 ; \mathrm{t}=1.63, P$-value $=0.05)$ and among obese $(1.3$ $\pm 1.1 ; \mathrm{t}=2.06, P$-value $=0.02) \mathrm{men}$. Overall, the mean pus cell/hpf among those with low progressive motion $(1.6 / \mathrm{hpf})$ was significantly higher $(\mathrm{t}=3.32, P$-value $=0.0005)$ than the mean pus cells/hpf of men with high progressive motility (1.4/hpf). In all, $92.5 \%$ of the men had pus cells of $1-2 / \mathrm{hpf}$ compared to on $7.4 \%$ of those who has pyospermia of $\geq 3 / \mathrm{hpf}$ (Table 1 ). Also, the $1.4 \pm 0.7 / \mathrm{hpf}$ mean

Table 1. Distribution of frequency (\%) andmeans ( \pm sd) of pus cells in all the patients by age, BMI, MPM and motility.

\begin{tabular}{|c|c|c|c|c|c|c|c|c|c|c|c|c|c|c|c|c|c|c|c|}
\hline \multirow{3}{*}{ Variable } & \multirow{3}{*}{ Sub-variable } & \multirow{3}{*}{ Freq. } & \multirow{3}{*}{$\%$} & \multirow{3}{*}{ Mean } & \multirow{3}{*}{ $\pm s d$} & \multirow{3}{*}{ Min. } & \multirow{3}{*}{ Max. } & \multicolumn{12}{|c|}{ Pus cells } \\
\hline & & & & & & & & \multicolumn{2}{|c|}{ All } & \multicolumn{2}{|c|}{0} & \multicolumn{4}{|c|}{$1-2$} & \multicolumn{4}{|c|}{$\geq 3$} \\
\hline & & & & & & & & Mean & $\pm s d$ & Freq. & $\%$ & Freq. & $\%$ & Mean & $\pm s d$ & Freq. & $\%$ & Mean & $\pm \mathrm{sd}$ \\
\hline \multirow{7}{*}{$\begin{array}{l}\text { Age group } \\
\text { (years) }\end{array}$} & All & 907 & 100.0 & 42.7 & 7.1 & 23 & 73 & 1.4 & 0.9 & 1 & 0.1 & 839 & 92.5 & 1.2 & 0.4 & 67 & 7.4 & 3.4 & 0.7 \\
\hline & $\leq 30$ & 13 & 1.4 & 27.6 & 1.6 & 23 & 29 & 1.4 & 0.6 & 0 & 0.0 & 12 & 1.3 & 1.2 & 0.4 & 1 & 1.5 & 3.0 & 0.0 \\
\hline & $30.1-35.0$ & 130 & 14.3 & 33.2 & 1.6 & 30 & 35 & 1.3 & 0.6 & 1 & 100.0 & 125 & 14.9 & 1.3 & 0.4 & 4 & 6.0 & 3.7 & 0.5 \\
\hline & $35.1-40.0$ & 233 & 25.7 & 38.3 & 1.4 & 36 & 40 & 1.4 & 0.7 & 0 & 0 & 217 & 25.9 & 1.2 & 0.4 & 16 & 23.9 & 3.3 & 0.6 \\
\hline & $40.1-45.0$ & 232 & 25.6 & 42.8 & 1.4 & 41 & 45 & 1.4 & 0.7 & 0 & 0 & 216 & 25.7 & 1.2 & 0.4 & 16 & 23.9 & 3.6 & 0.6 \\
\hline & $45.1-50.0$ & 173 & 19.1 & 47.8 & 1.3 & 46 & 50 & 1.5 & 1.1 & 0 & 0 & 156 & 18.6 & 1.3 & 0.4 & 17 & 25.4 & 3.9 & 2.2 \\
\hline & $>50$ & 126 & 13.9 & 54.8 & 3.9 & 51 & 73 & 1.6 & 1.2 & 0 & 0 & 113 & 13.5 & 1.3 & 0.5 & 13 & 19.4 & 4.0 & 2.3 \\
\hline \multirow{4}{*}{$\begin{array}{c}\text { BMI } \\
\left(\mathrm{kg} / \mathrm{m}^{2}\right)\end{array}$} & All & 907 & 100.0 & 27.1 & 3.9 & 18.9 & 70.0 & 1.4 & 0.9 & 1 & 0.1 & 839 & 92.5 & 1.2 & 0.4 & 67 & 7.4 & 3.4 & 0.7 \\
\hline & $18.0-24.5$ & 268 & 29.6 & 23.2 & 1.4 & 18.9 & 25.0 & 1.5 & 0.8 & 1 & 100.0 & 246 & 29.3 & 1.3 & 0.4 & 21 & 31.3 & 3.7 & 0.9 \\
\hline & $25.0-29.9$ & 468 & 51.6 & 27.2 & 1.3 & 25.0 & 30.0 & $1.4^{\wedge}$ & 0.8 & 0 & 0 & 431 & 51.4 & 1.2 & 0.4 & 37 & 55.2 & 3.5 & 1.9 \\
\hline & $\geq 30$ & 171 & 18.8 & 32.9 & 3.9 & 30.0 & 70.0 & $1.3^{\wedge} \wedge$ & 1.1 & 0 & 0 & 162 & 19.3 & 1.2 & 0.4 & 9 & 13.4 & 4.3 & 2.9 \\
\hline \multirow{3}{*}{$\begin{array}{c}\text { Motility } \\
(\%)\end{array}$} & All & 907 & 100.0 & 38.2 & 21.5 & 0 & 90 & 1.4 & 0.9 & 1 & 0.1 & 839 & 92.5 & 1.2 & 0.4 & 67 & 7.4 & 3.4 & 0.7 \\
\hline & $<32$ & 301 & 33.2 & 12.1 & 12.3 & 0 & 31 & $1.55 !$ & 1.1 & 1 & 100.0 & 271 & 32.3 & 1.3 & 0.5 & 29 & 43.3 & 4.0 & 2.2 \\
\hline & $\geq 32$ & 606 & 66.8 & 51.1 & 10.7 & 32 & 90 & $1.36 !$ & 0.7 & 0 & 0.0 & 568 & 67.7 & 1.2 & 0.4 & 38 & 56.7 & 3.4 & 0.6 \\
\hline \multirow{3}{*}{$\begin{array}{l}\text { Oval heads } \\
(\%)\end{array}$} & All & 907 & 100.0 & 39.8 & 17.4 & 0 & 60 & 1.4 & 0.9 & 1 & 0.1 & 839 & 92.5 & 1.2 & 0.4 & 67 & 7.4 & 3.4 & 0.7 \\
\hline & $\leq 30$ & 224 & 24.7 & 13.8 & 13.8 & 0 & 30 & $1.6^{*}$ & 1.3 & 1 & 0.9 & 198 & 23.6 & 1.2 & 0.4 & 25 & 37.2 & 4.4 & 2.3 \\
\hline & $>30$ & 683 & 75.3 & 48.3 & 6.8 & 35 & 60 & $1.4^{\star}$ & 0.6 & 0 & 0 & 641 & 76.4 & 1.3 & 0.4 & 42 & 62.7 & 3.3 & 0.5 \\
\hline
\end{tabular}

$\wedge \mathrm{t}=1.63, P$-value $=0.05 ; \wedge \wedge \mathrm{t}=2.06, P$-value $=0.02 ; \mathrm{t}=3.32, P$-value $=0.000 ;{ }^{\star} \mathrm{t}=2.22, P$-value $=0.013$. 
pus cells in the seminal fluid of men normal morphology (oval head) $\geq 20$ ( $\mathrm{n}=$ 796) was significantly lower than the $1.6 \pm 1.6 / \mathrm{hpf}$ observed among men with normal morphology $<20 \%(\mathrm{n}=111)$.

\subsection{Normospermic Patients}

The patients were then segregated into normospermic (452, 49.8\%), oligoospermic $(346,38.1 \%)$ and azoospermic $(109,12.1 \%)$ groups. Table 2 illustrates the distribution of the mean of pus cells and the proportion of men with different categories of pus cells relative to age, BMI and progressive motility. Those aged 35.1 to 45.0 years formed the highest proportion of normospermic group of patients with the highest proportion $(234,51.8 \%)$ who were overweight or with high progressive motility (393, 87.0\%). Overall, 410 (90.7\%) of normospermic men had sperms that contained $>30 \%$ oval heads while only $42(9.3 \%)$ had sperms that contain oval heads of $\leq 30 \%$. Overall, the mean $( \pm)$ of pus cells was $1.4(0.7)$. Those aged $<30$ had the lowest mean $( \pm)$ pus cells of $1.0(0.0)$ which was significantly lower $(\mathrm{t}=-15.94, P$-value $=0.00001)$ than the mean pus cell $( \pm)$ of men $>50$-year-old, though this might be due to the small number of men aged $<30$. However, men with normal BMI had mean $( \pm)$ pus cells of $1.5(0.8)$

Table 2. Distribution of mean ( \pm sd) and frequency (\%) of pus cells in normospermic patients by age and BMI.

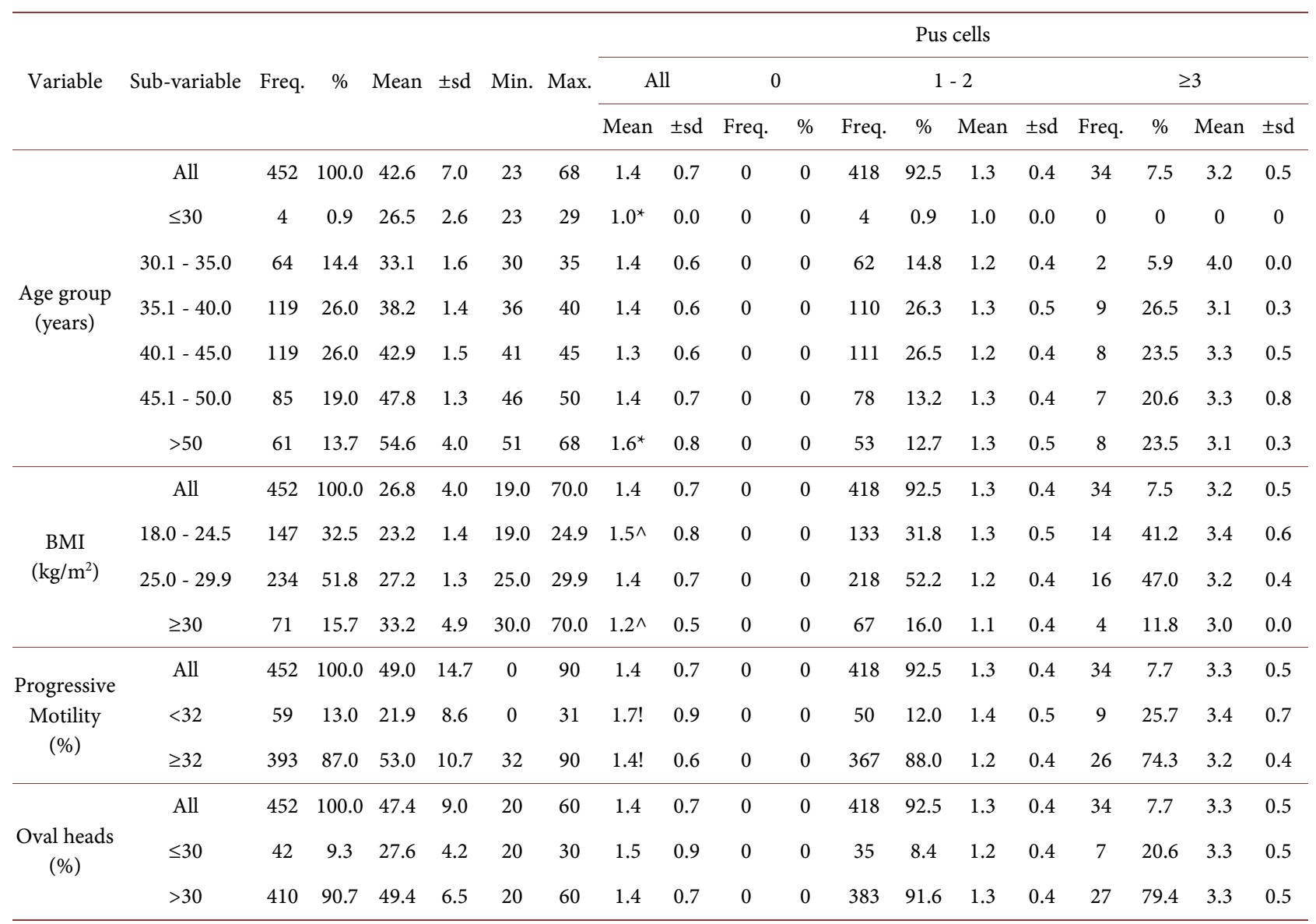

${ }^{*} \mathrm{t}=-15.94, P$-value $=0.00001 ; \wedge \mathrm{t}=3.38, P$-value $=0.0004 ; ! \mathrm{t}=2.48, P$-value $=0.008$. 
which was significantly higher than the $1.2(0.5)$ observed among obese men. Likewise, those with sperms' progressive motility $<32 \%$ had a mean $( \pm)$ pus cells of $1.7(0.9)$ which was expressively higher $(\mathrm{t}=3.38, P$-value $=0.0004)$ than the 1.4 (0.6) recorded for men whose sperms' progressive motility was $\geq 32 \%$. In all, $418(92.5 \%)$ of normospermic men had pus cells of 1 - 2/hpf, observed mainly among those aged 40.1 - 45 years $(11 / 4181,26.5 \%)$, compared to only $34(7.5 \%)$ who had pus cells of $\geq 3 /$ hpf mainly among those aged 35.1 - 40 years $(9 / 34$, $26.5 \%)$.

Mean pus cells of $1.4 \pm 0.7 / \mathrm{hpf}$ mean pus cells was recorded for normospermic men normal sperm morphology (oval head) of $\geq 20 \%$ ( $n=452$ ). No normospermic men had oval head sperms of $<20 \%(n=0)$.

\subsection{Oligoospermic Patients}

A total of 346 (38.1\%) out of the initial 907 men were oligoospermic, mostly in the age group of $40.1-45.0(87,25.1 \%)$, overweight $(174,50.3 \%)$ and with motility of $\geq 32 \%(212,61.3 \%)$ (Table 3$)$. In all, $272(78.6 \%)$ had sperms that contained oval heads $>30 \%$ while $74(21.4 \%)$ had sperms that contained oval heads of $\leq 30 \%$ indicating an increase of $12.1 \%$ in men whose sperms contained oval head $\leq 30 \%$. There were more men in the oligoospermic cluster whose population of sperms with oval head was $\leq 30 \%$. The overall mean ( \pm ) pus cells of 1.40 (0.7) was not significantly different from that of normospermic patients. However, the mean $( \pm)$ pus cells of $1.6(0.8)$ observed among men aged $\geq 30$ years was the highest though not significantly varied from those of other age groups. The mean $( \pm)$ pus cells of $1.4(0.7) /$ hpf observed among oligoospermic normal weight men was significantly higher $(\mathrm{t}=2.18, P$-value $=0.015)$ than the 1.2 $(0.5) / \mathrm{hpf}$ recorded for oligoospermic obese men. Further, there was a noteworthy variation $(\mathrm{t}=2.59, P$-value $=0.005)$ in the mean $( \pm)$ pus cells of $1.5(0.7) / \mathrm{hpf}$ recorded for oligoospermic men with progressive motility of $<32 \%$ when compared with the $1.3(0.7) / \mathrm{hpf}$ observed among oligoospermic men with progressive motility $\geq 32 \%$. A total of $323(93.3 \%)$ men had pus cells of $1-2 /$ hpf and only 23 (6.7\%) had pus cells of $\geq 3 / \mathrm{hpf}$.

The $1.4 \pm 0.7 / \mathrm{hpf}$ mean pus cells in the seminal fluid of oligoospermic men with normal morphology (oval head) $\geq 20(\mathrm{n}=342$ ) was not significantly different from the $2.0 \pm 1.4 / \mathrm{hpf}$ observed among those with normal morphology < $20 \%(n=4)$.

\subsection{Azoospermic Patients}

There were 109 men with azoospermia with 28 (25.7\%) of them aged $35.1-40.0$ years, $60(55.0 \%)$ of them being overweight (Table 4). This cluster had no sperm cells thus progressive motility and sperm morphology calculation could not occur. However, a mean $( \pm)$ pus cells of $2.3(2.7) / \mathrm{hpf}$ was recorded among those of them aged $>50$ years which was significantly higher $(\mathrm{t}=1.86, P$-value $=0.04)$ than the $1.1(0.4) / \mathrm{hpf}$ observed among those aged $30.1-35.0$ years only. The 
Table 3. Distribution of mean ( \pm sd) and frequency (\%) of pus cells in oligoospermic patients by age and BMI.

\begin{tabular}{|c|c|c|c|c|c|c|c|c|c|c|c|c|c|c|c|c|c|c|c|}
\hline \multirow{3}{*}{ Variable } & \multirow{3}{*}{ Sub-variable } & \multirow{3}{*}{ Freq. } & \multirow{3}{*}{$\%$} & \multirow{3}{*}{ Mean } & \multirow{3}{*}{ $\pm s d$} & \multirow{3}{*}{ Min. } & \multirow{3}{*}{ Max. } & \multicolumn{12}{|c|}{ Pus cells } \\
\hline & & & & & & & & \multicolumn{2}{|c|}{ All } & \multicolumn{2}{|c|}{0} & \multicolumn{4}{|c|}{$1-2$} & \multicolumn{4}{|c|}{$\geq 3$} \\
\hline & & & & & & & & Mean & $\pm s d$ & Freq. & $\%$ & Freq. & $\%$ & Mean & $\pm s d$ & Freq. & $\%$ & Mean & $\pm s d$ \\
\hline \multirow{7}{*}{$\begin{array}{l}\text { Age group } \\
\text { (years) }\end{array}$} & All & 346 & 100.0 & 42.8 & 7.1 & 27.0 & 73 & 1.40 & 0.7 & 0 & 0 & 323 & 93.3 & 1.2 & 0.4 & 23 & 6.7 & 3.5 & 0.7 \\
\hline & $\leq 30$ & 7 & 2.0 & 28.1 & 0.7 & 27.0 & 29.0 & 1.6 & 0.8 & 0 & 0 & 6 & 1.9 & 1.3 & 0.5 & 1 & 4.3 & 1.0 & 0.0 \\
\hline & $30.1-35.0$ & 49 & 14.2 & 33.3 & 1.6 & 30.0 & 35.0 & 1.4 & 0.6 & 0 & 0 & 47 & 14.5 & 1.3 & 0.5 & 2 & 8.7 & 3.5 & 0.7 \\
\hline & $35.1-40.0$ & 86 & 24.9 & 38.4 & 1.4 & 36.0 & 40.0 & 1.4 & 0.7 & 0 & 0 & 81 & 25.2 & 1.2 & 0.4 & 5 & 21.7 & 3.4 & 0.9 \\
\hline & $40.1-45.0$ & 87 & 25.1 & 42.9 & 1.4 & 41.0 & 45.0 & 1.4 & 0.8 & 0 & 0 & 81 & 25.1 & 1.2 & 0.4 & 6 & 26.1 & 3.7 & 0.8 \\
\hline & $45.1-50.0$ & 70 & 20.2 & 47.9 & 1.3 & 46.0 & 50.0 & 1.5 & 0.9 & 0 & 0 & 62 & 19.2 & 1.2 & 0.4 & 8 & 34.8 & 3.5 & 0.8 \\
\hline & $>50$ & 47 & 13.6 & 54.9 & 3.9 & 51.0 & 73.0 & 1.3 & 0.5 & 0 & 0 & 46 & 14.2 & 1.3 & 0.5 & 1 & 2.1 & 3.0 & 0.0 \\
\hline \multirow{4}{*}{$\begin{array}{c}\text { BMI } \\
\left(\mathrm{kg} / \mathrm{m}^{2}\right)\end{array}$} & All & 346 & 100.0 & 27.2 & 3.6 & 18.9 & 44.8 & 1.4 & 0.7 & 0 & 0 & 323 & 93.3 & 1.2 & 0.4 & 23 & 6.7 & 3.5 & 0.7 \\
\hline & $18.0-24.5$ & 98 & 28.3 & 23.2 & 1.3 & 18.9 & 24.9 & $1.4 !$ & 0.7 & 0 & 0 & 93 & 28.8 & 1.3 & 0.4 & 5 & 21.8 & 3.8 & 0.8 \\
\hline & $25.0-29.9$ & 174 & 50.3 & 27.1 & 1.3 & 25.0 & 29.9 & 1.5 & 0.8 & 0 & 0 & 157 & 48.6 & 1.2 & 0.4 & 17 & 73.9 & 3.4 & 0.7 \\
\hline & $\geq 30$ & 74 & 21.4 & 32.5 & 2.3 & 30.0 & 44.8 & $1.2 !$ & 0.5 & 0 & 0 & 73 & 22.6 & 1.2 & 0.4 & 1 & 4.3 & 3.0 & 0.0 \\
\hline \multirow{3}{*}{$\begin{array}{c}\text { Motility } \\
(\%)\end{array}$} & All & 346 & 100.0 & 49.0 & 14.7 & 0.0 & 87.5 & 1.4 & 0.7 & 0 & 0 & 323 & 93.3 & 1.2 & 0.4 & 23 & 6.7 & 3.5 & 0.7 \\
\hline & $<32$ & 134 & 38.7 & 17.8 & 10.6 & 0.0 & 31.0 & $1.5^{*}$ & 1.0 & 0 & 0 & 123 & 30.1 & 1.3 & 0.5 & 11 & 47.8 & 3.2 & 0.4 \\
\hline & $\geq 32$ & 212 & 61.3 & 47.6 & 9.6 & 33.0 & 87.5 & 1.3 & 0.7 & 0 & 0 & 200 & 69.9 & 1.2 & 0.4 & 12 & 52.2 & 3.8 & 0.9 \\
\hline \multirow{3}{*}{$\begin{array}{c}\text { Oval } \\
\text { heads }(\%)\end{array}$} & All & 346 & 100.0 & 42.3 & 11.0 & 5.0 & 60.0 & 1.4 & 0.7 & 0 & 0 & 323 & 93.3 & 1.2 & 0.4 & 23 & 6.7 & 3.5 & 0.7 \\
\hline & $\leq 30$ & 74 & 21.4 & 25.7 & 6.1 & 5 & 30 & 1.5 & 1.0 & 0 & 0 & 66 & 20.4 & 1.3 & 0.4 & 8 & 34.8 & 3.9 & 1.0 \\
\hline & $>30$ & 272 & 78.6 & 46.8 & 7.0 & 35 & 60 & 1.4 & 0.6 & 0 & 0 & 257 & 79.6 & 1.2 & 0.4 & 15 & 65.2 & 3.3 & 0.5 \\
\hline
\end{tabular}

$! \mathrm{t}=2.18, P$-value $=0.015 ;{ }^{*} \mathrm{t}=2.59, P$-value $=0.005$.

Table 4. Distribution of mean ( \pm sd) and frequency (\%) of pus cells in azoospermic patients by age and BMI.

\begin{tabular}{|c|c|c|c|c|c|c|c|c|c|c|c|c|c|c|c|c|c|c|c|}
\hline \multirow{3}{*}{ Variable } & \multirow{3}{*}{ Sub-variable } & \multirow{3}{*}{ Freq. } & \multirow{3}{*}{$\%$} & \multirow{3}{*}{ Mean } & \multirow{3}{*}{ $\pm s d$} & \multirow{3}{*}{ Min. } & \multirow{3}{*}{ Max. } & \multicolumn{12}{|c|}{ Pus cells } \\
\hline & & & & & & & & \multicolumn{2}{|c|}{ All } & \multicolumn{2}{|c|}{0} & \multicolumn{4}{|c|}{$1-2$} & \multicolumn{4}{|c|}{$\geq 3$} \\
\hline & & & & & & & & Mean & $\pm \mathrm{sd}$ & Freq. & $\%$ & Freq. & $\%$ & Mean & \pm sd & Freq. & $\%$ & Mean & $\pm s d$ \\
\hline \multirow{7}{*}{$\begin{array}{l}\text { Age } \\
\text { group } \\
\text { (years) }\end{array}$} & All & 109 & 100.0 & 42.6 & 7.7 & 28.0 & 62.0 & 1.6 & 1.6 & 1 & 0.9 & 98 & 89.9 & 1.2 & 0.4 & 10 & 9.2 & 5.5 & 3.3 \\
\hline & $\leq 30$ & 2 & 1.8 & 28.0 & 0.0 & 28.0 & 28.0 & 1.5 & 0.7 & 0 & 0.0 & 2 & 100.0 & 1.5 & 0.7 & 0 & 0.0 & 0.0 & 0.0 \\
\hline & $30.1-35.0$ & 17 & 15.6 & 32.9 & 1.3 & 30.0 & 35.0 & $1.1^{\star}$ & 0.4 & 1 & 100.0 & 16 & 94.1 & 1.1 & 0.3 & 0 & 0.0 & 0.0 & 0.0 \\
\hline & $35.1-40.0$ & 28 & 25.7 & 38.1 & 1.3 & 36.0 & 40.0 & 1.4 & 0.8 & 0 & 0.0 & 26 & 92.9 & 1.1 & 0.4 & 2 & 7.1 & 4.0 & 0.0 \\
\hline & $40.1-45.0$ & 26 & 23.9 & 42.3 & 1.3 & 41.0 & 45.0 & 1.4 & 0.9 & 0 & 0.0 & 24 & 92.3 & 1.2 & 0.4 & 2 & 7.7 & 4.0 & 0.0 \\
\hline & $45.1-50.0$ & 18 & 16.5 & 47.7 & 1.5 & 46.0 & 50.0 & 2.0 & 2.7 & 0 & 0.0 & 16 & 88.9 & 1.3 & 0.5 & 2 & 11.1 & 7.5 & 6.4 \\
\hline & $>50$ & 18 & 16.5 & 55.3 & 3.7 & 51.0 & 62.0 & 2.3 & 2.7 & 0 & 0.0 & 14 & 77.8 & 1.2 & 0.4 & 4 & 22.2 & 6.0 & 3.6 \\
\hline \multirow{4}{*}{$\begin{array}{c}\text { BMI } \\
\left(\mathrm{kg} / \mathrm{m}^{2}\right)\end{array}$} & All & 109 & 100.0 & 28.0 & 4.2 & 19.4 & 48.7 & 1.6 & 1.6 & 1 & 0.9 & 98 & 89.9 & 1.2 & 0.4 & 10 & 9.2 & 5.5 & 3.3 \\
\hline & $18.0-24.5$ & 23 & 21.1 & 22.8 & 1.6 & 19.4 & 24.8 & 1.5 & 1.2 & 1 & 100.0 & 20 & 87.0 & 1.2 & 0.4 & 2 & 8.7 & 5.0 & 1.4 \\
\hline & $25.0-29.9$ & 60 & 55.0 & 27.8 & 1.3 & 25.1 & 29.9 & 1.5 & 1.4 & 0 & 0.0 & 56 & 93.3 & 1.2 & 0.4 & 4 & 6.7 & 5.2 & 3.9 \\
\hline & $\geq 30$ & 26 & 23.9 & 33.3 & 4.1 & 30.1 & 48.7 & 1.8 & 2.3 & 0 & 0.0 & 22 & 84.6 & 1.1 & 0.3 & 4 & 15.4 & 6.0 & 4.0 \\
\hline \multirow{3}{*}{$\begin{array}{c}\text { Motility } \\
(\%)\end{array}$} & All & 109 & 100.0 & 0.0 & 0.0 & 0.0 & 0.0 & 0.0 & 0.0 & 0 & 0.0 & 99 & 90.8 & 1.2 & 0.4 & 10 & 9.2 & 5.5 & 3.3 \\
\hline & $<32$ & 109 & 100.0 & 0.0 & 0.0 & 0.0 & 0.0 & 0.0 & 0.0 & 0 & 0.0 & 0 & 0.0 & 0.0 & 0.0 & 0 & 0.0 & 0 & 0.0 \\
\hline & $\geq 32$ & 0 & 0.0 & 0.0 & 0.0 & 0.0 & 0.0 & 0.0 & 0.0 & 0 & 0.0 & 0 & 0.0 & 0.0 & 0.0 & 0 & 0.0 & 0 & 0.0 \\
\hline \multirow{3}{*}{$\begin{array}{c}\text { Oval } \\
\text { heads }(\%)\end{array}$} & All & 109 & 100.0 & 0.0 & 0.0 & 0.0 & 0.0 & 1.6 & 1.6 & 0 & 0.0 & 99 & 90.8 & 1.2 & 0.4 & 10 & 9.2 & 5.5 & 3.3 \\
\hline & $<20$ & 0 & 0 & 0.0 & 0.0 & 0.0 & 0.0 & 0.0 & 0.0 & 0 & 0.0 & 0 & 0.0 & 0.0 & 0.0 & 0 & 0.0 & 0.0 & 0.0 \\
\hline & $\geq 20$ & 0 & 0 & 0.0 & 0.0 & 0.0 & 0.0 & 0 & 0 & 0 & 0 & 0 & 0 & 0 & 0 & 0 & 0 & 0 & 0 \\
\hline
\end{tabular}


highest mean $( \pm)$ pus cells of $1.8(2.3) / \mathrm{hpf}$ seen in azoospermic obese men was not significantly varied from other the mean $( \pm)$ pus cells of other BMI groups. The observed mean $( \pm)$ pus cells among these azoospermic patients was 1.6 (1.6)/hpf. Overall, 99 (90.8\%) of them men had pus cells of $1-2 /$ hpf and only 10 (9.2\%) had pus cells of $\geq 3 / \mathrm{hpf}$.

Figure 1 depicts the means of pus cells in the three categories of patients indicating that pus cells $\geq 3 /$ hpf were more prevalent in the seminal fluid of azoospermic men while pus cells of $1-2 / \mathrm{hpf}$ were more prevalent in the seminal fluids of men with normal seminal fluid. Further, pus cells were fewer in the seminal fluid of men with progressive motility of $<32 \%$ regardless of whether they were normospermic, oligoospermic or azoospermic (Figure 2). Table 5 shows that of the three groups of patients, azoospermic group were 1.33 more likely to present with high pus count in their seminal fluid $\left(x^{2}=0.62, P\right.$-value $=0.43$, Crude Odds ratio $=1.33$ ) than normospermic or oligoospermic patients.

In all the patients, age, BMI, sperm count, and pus cells gave a significant $29.9 \%$ explanation of the variations observed in progressive motility $\left(\mathrm{R}^{2}=\right.$ $0.2992, P$-value $=0.00001)$ and a significant $21.72 \%$ explanation of the variation seen in oval head sperm morphology (in Table 6). Progressive motility had a

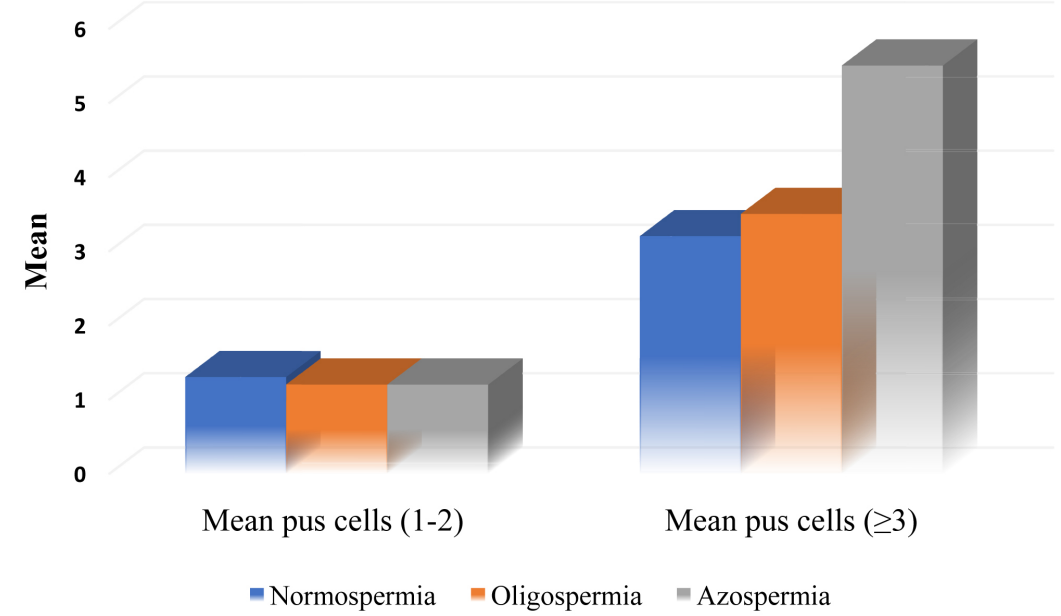

Figure 1. Means of pus cells among normospermic, oligoospermic and azoospermic men according number of pus cells/hpf.

Table 5. Chi-square analysis of categories of sperm count and pus cells/hpf.

\begin{tabular}{|c|c|c|c|c|c|c|c|c|c|}
\hline \multirow{3}{*}{ Variable } & \multirow{3}{*}{ Total } & \multicolumn{4}{|c|}{ Pus cells/hpf } & \multirow{3}{*}{$x^{2}$} & \multirow{3}{*}{$P$-value } & \multirow{3}{*}{$\begin{array}{l}\text { Crude } \\
\text { Odds } \\
\text { Ratio }\end{array}$} & \multirow{3}{*}{$\begin{array}{c}95 \% \\
\text { Confidence } \\
\text { Interval }\end{array}$} \\
\hline & & \multicolumn{2}{|c|}{$1-2$} & \multicolumn{2}{|c|}{$\geq 3$} & & & & \\
\hline & & Freq. & $\%$ & Freq. & $\%$ & & & & \\
\hline Normospermic & 452 & 418 & 92.5 & 34 & 7.5 & 0.02 & 0.88 & 1.04 & $0.63,1.71$ \\
\hline Oligoospermic & 346 & 323 & 93.3 & 23 & 6.7 & 0.46 & 0.50 & 0.83 & $0.49,1.41$ \\
\hline Azoospermic & 108 & 98 & 90.7 & 10 & 9.3 & 0.62 & 0.43 & 1.33 & $0.66,2.68$ \\
\hline Total & 906 & 839 & 92.6 & 67 & 7.4 & - & - & - & - \\
\hline
\end{tabular}

${ }^{\star}$ Note: One patient with no pus cells was excluded. 


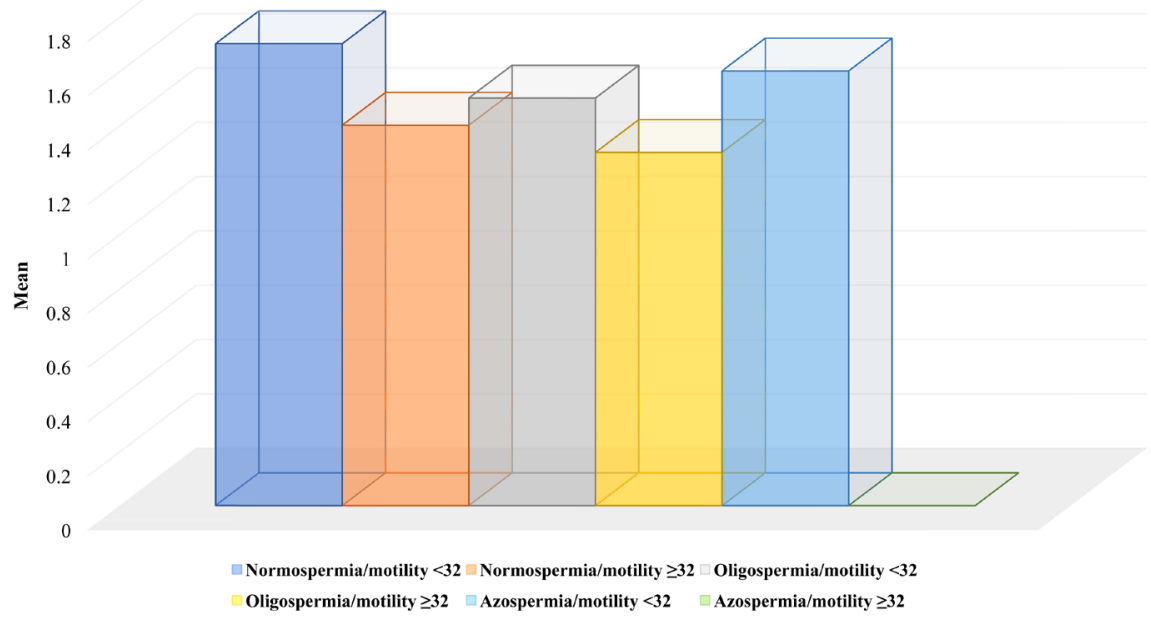

Figure 2. Distribution of mean count of pus cells among normospermic, oligoospermic and azoospermic patients with normal $(\geq 32 \%)$ or abnormal $(<32 \%)$ sperm progressive motility.

Table 6. Multivariate regression analysis with progressive motility and oval heads as dependent variable and Age BMI, Spermcount and Puscells as independent variables.

\begin{tabular}{|c|c|c|c|c|c|c|c|}
\hline Equation & Obs & Parms & RMSE & $\mathbf{R}^{2}$ & F-statistics & \multicolumn{2}{|c|}{$P$-value } \\
\hline $\begin{array}{c}\text { Progressive } \\
\text { motility }\end{array}$ & 907 & \multirow[t]{2}{*}{5} & 18.04966 & 0.2992 & 96.28511 & \multicolumn{2}{|c|}{0.0000} \\
\hline \multirow[t]{4}{*}{ Oval heads } & 907 & & 15.46425 & 0.2172 & 62.55451 & \multicolumn{2}{|c|}{0.0000} \\
\hline & & & Coefficient & Std. err. & t-statistics & $P$-value & $\begin{array}{c}95 \% \\
\text { Confidence } \\
\text { Interval }\end{array}$ \\
\hline & & Age & -0.07 & 0.08 & -0.80 & 0.42 & $-0.23,0.10$ \\
\hline & & BMI & -0.34 & 0.15 & -2.19 & 0.03 & $-0.64,-0.03$ \\
\hline \multirow{3}{*}{\multicolumn{2}{|c|}{ Progressive Motility }} & $\begin{array}{l}\text { Sperm } \\
\text { count }\end{array}$ & 0.49 & 0.03 & 18.78 & 00001 & $0.44,0.54$ \\
\hline & & Pus cells & -3.04 & 0.70 & -4.37 & 00001 & $-4.44,-1.68$ \\
\hline & & Constant & 43.66 & 5.61 & 7.77 & 0.00 & $32.63,54.69$ \\
\hline \multirow{5}{*}{ Oval head m } & & Age & 0.02 & 0.07 & 0.22 & 0.82 & $-0.13,0.16$ \\
\hline & & BMI & -0.26 & 0.13 & -1.94 & 0.05 & $-0.51,0.00$ \\
\hline & ology & $\begin{array}{l}\text { Sperm } \\
\text { count }\end{array}$ & 0.34 & 0.02 & 15.27 & 0.00 & $0.30,0.38$ \\
\hline & & Pus cells & -1.75 & 0.60 & -2.93 & 0.003 & $-2.92,-0.58$ \\
\hline & & Constant & 40.95 & 4.81 & 8.51 & 0.000 & $31.50,50.40$ \\
\hline
\end{tabular}

strong negative and significant correlation with pus cells $(\mathrm{r}=-3.04, \mathrm{t}=-4.37$, $P$-value $=0.00001,95 \% \mathrm{CI}:-4.44,-1.68)$ and oval heads had a weaker negative and significant correlation with pus cells $(\mathrm{r}=-1.75, \mathrm{t}=-2.93, P$-value $=0.003$, 95\% CI: $-2.92,-0.58)$. 


\section{Discussion}

Infertility, both in males and in females, is now a growing problem in virtually all cultures and societies in the world, affecting at least $15 \%$ of couples or reproductive age [24]. Recently, the number of couples seeking treatment for infertility has dramatically increased perhaps due to availability of more successful techniques for infertility management and to high awareness of available services. Polis et al., [25] estimated that close to $1 / 3$ of Nigerian couples at the risk of pregnancy will have difficulty conceiving within 12 months, $17.7 \%$ within 24 months and $11.5 \%$ within 36 month-duration. Probably one of the reasons for having difficulty is the issue of pyospermia and its consequences on fertilization. Approximately $4 \%-10 \%$ cases of male infertility are caused by infections of the genital tract and inflammation process from these infections are responsible for the infiltration of leukocytes into seminal fluid thus reducing sperm motility, activating acrosome reaction, and diminishing fertilization potential of sperms, making achievement of pregnancy more difficult for the couple [16].

There are some key findings in this study that reflect the dangers pyospermia poses to fertility. First, $452(49.8 \%)$ of all the patients were normospermic a figure that was lesser than the 115 (57\%) reported by Kjaergaard et al., [26] in their study. The mean age ( \pm sd) of patients was 42.7 (7.1) years which was slightly higher than the 38.7 years $( \pm 7.1)$ reported from a similar study in Dakar, Senegal [27] indicating that Nigerian males reporting for infertility are still older, in their $4^{\text {th }}$ decade of life. In all the patients, $7.4 \%$ of infertile men had pyospermia of $\geq 3 /$ hpf which is much lower than the $23 \%$ reported by Jarvi and Noss [28]. The mean $( \pm)$ pus cells of $1.6(1.2) / \mathrm{hpf}$ observed in this study is also less than the 3.29/hpf reported by Khan et al., [29]. Sexual abstinence can have an influence on leucocytospermia, as the more time sperms remain in the epididymis, the greater the number of macrophages and granulocytes that will be attracted by older sperm, which can cause an elevated level of leukocytes in the ejaculate [16]. Vasovasostomy or vasectomy reversal tends to alter sperm parameters and cause sperm dysfunction, due chiefly to the presence of high levels of Reactive Oxygen Species (ROS). There is direct link between an increase in the ROS levels and the presence of WBCs in the semen [16]. Men with normal BMI had significantly higher mean pus cells than the overweight and obese men. This is the first time this is reported in sub-Saharan Africa and this paper can only speculate that this may be due to higher sexuality among men with normal weight for age. Further studies are needed to clarify this finding. Also, those whose sperms had $\leq 30 \%$ normal morphology (oval heads) had higher mean pus cells than those whose sperms had $>30 \%$ normal morphology (oval head) which agrees with the findings of Khan et al. [29]. The observed inverse relationship between motility and pus cells accord with the findings of Enwuru et al., [20].

Secondly, in normospermic cluster of men, mean of pus cells was highest among men aged over 50 years. This is in sharp contrast to the findings of a phenomenon that may be attributable to prostatitis or to multiple sexual part- 
ners. Again, pus cells were significantly higher in men with normal BMI than in obese men, probably for the same reason discussed above. Pus cells were also observed to be inversely related to both sperm progressive motility and to sperm normal morphology, findings that resonate with the report of Khan et al., [29] from Pakistan.

Thirdly, there were $346(38.1 \%)$ men in the oligozoospermic cluster,a figure lower than the 52.5\% oligozoospermic patients reported by Enwuru et al. [20]. Pus cells were not significantly altered in the different age groups but were higher in men with normal BMI than in obese men and pus cells were still inversely associated to sperm progressive motility as reported earlier by Khan et al. [29] but not to sperm normal morphology. It is possible that there may be a mechanism, probably an immunological apparatus, preventing ROS from attacking sperm cells in oligoospermic patient. For example, Moretti et al., [30] documented that some component of sperm flagella i.e. tubulin, found in the axoneme and bacterial proteins may have antigenic mimicry which could be pathogenic to the sperm cells. Leucocytospermia may thus trigger antibodies and T-cells to react against bacterial cell constituents that may recognize mirror-image in the sperm cells bringing about immune-mediated damage. This might be one of the pathways where damage to the sperm cells occurs [31].

Lastly, 109 (12.0\%) men were in the azoospermia cluster. This is lower than the $14.1 \%$ reported from Senegal [27] but accords with the 203 (12.5\%) reported by Khan et al., [29]. The overall mean pus cell in the azoospermia cluster was 1.6 (1.6)/hpf which is lower than the $3.25 \pm 0.26$ reported from Pakistan [29]. This cluster had the lowest proportion of men with pus cells of $1-2 / \mathrm{hpf}$, the highest proportion of those with pus cells of $\geq 3 / \mathrm{hpf}$ and the highest mean pus cells of 5.5 (3.3) among those who had pyospermia of $\geq 3 / \mathrm{hpf}$. Infection induces reactive oxygen species production, decreases the total antioxidant capacity and sperm DNA fragmentation or antigen production that lead to sperm dysfunctions and DNA fragmentation [18].

\section{Conclusion}

To conclude, this study leans towards the belief that pyospermia affects the quality of sperm because high pus cell counts were seen more in azoospermic than in oligoospermic or normospermic patients, contrary to what Enwuru et al. [20] reported. This appears to be a confirmation that pyospermia could be one of the characteristic sources of infertility in the human male. This study also shows that infection in the semen is most likely associated with low and abnormal sperm motility. Furthermore, an inverse relationship was found between pus cell count and the number of sperm cells with oval head morphology. Clinicians in the field of male infertility should always be on the lookout for pus cells in the semen which, if left untreated could further aggravate male infertility. It is obvious that further studies on pyospermia of bacterial, viral, fungi or any other origin, are needed, especially in sub-Saharan Africa where male infertility is topic and 
microbial organisms are prevalent.

\section{Strengths and Limitations}

This study is part of a larger study and the strengths and limitations had already been documented [32]. In summary however, the strengths included strict adherence to the collection of semen samples, since each couple was well-informed ahead of before sample collection. Confidence building was actualized such that all patients felt free to abide by the regulations of the Fertility Center. Anthropometric measurements were conducted in the clinic and not volunteered by patients. Modern laboratory medical equipment and reagents are available at the Fertility Center for the analysis of all samples and all cases. Each analysis was on two consecutive samples. Finally, there were a large sample size of overweight and obese patients and the same study criteria were used for all the patients. Concerning limitations, the semen samples were from different locations and the samples were analyzed in three different laboratories of the same organization with the possibility of inter-laboratory variation. However, almost all the samples were examined twice with quite insignificant difference in the results. Because the study was facility-based, the findings on semen analysis, anthropometry and other variables may not reflect what is expected at community level. Finally, this study did not have data for underweight or morbidly obese men.

\section{Authors' Contribution}

ABA, BMA and VDA conceived of the study, participated in its design, and helped to draft the manuscript. BMA participated in its design, performed the statistical analysis, and drafted the manuscript. IO and OB, oversaw examination, recruitment of patients into the study, sample collection, and supervision of the clinical aspects of the study. AA supervised all laboratory work. All authors read and approved the final manuscript.

\section{Competing Interest}

All authors declare no competing interests.

\section{References}

[1] Emokpae, M.A., Mohammed, A.Z. and Omale-Itodo, A. (2006) Hormonal Abnormalities in Azoospermic Men in Kano, Northern Nigeria. Indian Journal of Medical Research, 124, 299-304.

[2] Ameh, N., Kene, T.S., Onuh, S.O., Okohue, J.E., Umeora, O.U. and Anozie, O.B. (2007) Burden of Domestic Violence amongst Infertile Women Attending Infertility Clinics in Nigeria. Nigerian Journal of Medicine, 16, 375-377.

[3] Dhont, N., Muvunyi, C., Luchters, S., Vyankandondera, J., De Naeyer, L., Temmerman, M. and van de Wijgert, J. (2011) HIV Infection and Sexual Behaviour in Primary and Secondary Infertile Relationships: A Case-Control Study in Kigali, Rwanda. Sexually Transmitted Infections, 87, 28-34. https://doi.org/10.1136/sti.2010.042879 
[4] Dhont, N., van de Wijgert, J., Coene, G., Gasarabwe, A. and Temmerman, M. (2011) "Mama and Papa Nothing": Living with Infertility among an Urban Population in Kigali, Rwanda. Human Reproduction, 26, 623-629.

https://doi.org/10.1093/humrep/deq373

[5] Wiersema, N.J., Drukker, A.J., Dung, M.B.T., Nhu, G.H., Nhu, N.T. and Lambalk, C.B. (2006) Consequences of Infertility in Developing Countries: Results of a Questionnaire and Interview Survey in the South of Vietnam. Journal of Translational Medicine, 4, 54. https://doi.org/10.1186/1479-5876-4-54

[6] Basso, O., Weinberg, C.R., Baird, D.D., Wilcox, A.J. and Olsen, J. (2003) Subfecundity as a Correlate of Preeclampsia: A Study within the Danish National Birth Cohort. American Journal of Epidemiology, 157, 195-202.

https://doi.org/10.1093/aje/kwf194

[7] Buck Louis, G.M., Cooney, M.A. and Peterson, C.M. (2011) The Ovarian Dysgenesis Syndrome. Journal of Developmental Origins of Health and Disease, 2, 25-35. https://doi.org/10.1017/S2040174410000693

[8] Raatikainen, K., Harju, M., Hippelainen, M. and Heinonen, S. (2010) Prolonged Time to Pregnancy Is Associated with a Greater Risk of Adverse Outcomes. Fertility and Sterilty, 94, 1148-1151. https://doi.org/10.1016/j.fertnstert.2009.10.058

[9] Rouchou, B. (2013) Consequences of Infertility in Developing Countries. Perspectives in Public Health, 133, 174-179. https://doi.org/10.1177/1757913912472415

[10] Abdallah, S. and Daar, Z.M. (2001) Infertility and Social Suffering: The Case of ART in Developing Countries. Section 1, Infertility and Assisted Reproductive Technologies in the Developing World. Current Practices and Controversies in Assisted Reproduction: Report of a Meeting on "Medical, Ethical and Social Aspects of Assisted Reproduction”, WHO Headquarters, Geneva, 17-21 September 2001, 15-21.

[11] Larsen, U. (2005) Research on Infertility: Which Definition Should We Use? Fertility and Sterility, 83, 846-852. https://doi.org/10.1016/j.fertnstert.2004.11.033

[12] Ajayi, A., Ajayi, V., Biobaku, O., Oyetunji, I., Aikhuele, H. and Afolabi, B.M. (2017) Awareness, Knowledge and Perception of In-Vitro Fertilization among Final-Year Medical Students in South-West Nigeria. International Journal of Pregnancy \& Child Birth, 2, Articler ID: 00007.

[13] Cui, W. (2010) Mother or Nothing: The Agony of Infertility. Bulletin of the World Health Organization, 88, 881-882. https://doi.org/10.2471/BLT.10.011210

[14] Kurpisz, M.K., (2004) New Approach to Male Infertility: Forum Introductions. Reproductive Biology and Endocrinology, 2, 8. https://doi.org/10.1186/1477-7827-2-8

[15] Okonofua, F., Menakaya, U., Onemu, S.O., Omo-Aghoja, L.O. and Bergstrom, S. (2005) A Case-Control Study of Risk Factors of Male Infertility in Nigeria. Asian Journal of Andrology, 7, 351-361.

[16] Askienazy-Elbhar, M. (2005) Male Genital Tract Infection: The Point of View of the Bacteriologist. Gynécologie Obstétrique \& Fertilité, 33, 691-697.

https://doi.org/10.1016/j.gyobfe.2005.07.008

[17] Gallegos, G., Ramos, B., Santiso, R., Goyanes, V., Gosálvez, J. and Fernández, J.L. (2008) Sperm DNA Fragmentation in Infertile Men with Genitourinary Infection by Chlamydia Trachomatis and Mycoplasma. Fertility and Sterilty, 90, 328-334. https://doi.org/10.1016/j.fertnstert.2007.06.035

[18] Pourmasumi, S., Sabeti, P., Rahiminia, T., Mangoli, E., Tabibnejad, N. and Talebi, A.R. (2017) The Etiologies of DNA Abnormalities in Male Infertility: An Assessment and Review. International Journal of Reproductive Biomedicine, 15, 331-344. 
[19] Lewis, S.E., John Aitken, R., Conner, S.J., Iuliis, G.D., Evenson, D.P., Henkel, R., Giwercman, A. and Gharagozloo, P. (2013) The Impact of Sperm DNA Damage in Assisted Conception and beyond: Recent Advances in Diagnosis and Treatment. Reproductive BioMedicine Online, 27, 325-337. https://doi.org/10.1016/j.rbmo.2013.06.014

[20] Enwuru, C.A., Iwalokun, B., Enwuru, V.N., Ezechi, O. and Oluwadun, A. (2016) The Effect of Presence of Facultative Bacteria Species on Semen and Sperm Quality of Men Seeking Fertility Care. African Journal of Urology, 22, 213-222. https://doi.org/10.1016/j.afju.2016.03.010

[21] Onemu, S.O. and Ibeh, I.N. (2001) Studies on the Significance of Positive Bacterial Semen Cultures in Male Fertility in Nigeria. International Journal of Fertility and Women's Medicine, 46, 210-214.

[22] WHO (2010) WHO Laboratory Manual for the Examination and Processing of Human Semen. 5th Edition, World Health Organization, Geneva.

[23] World Health Organization (2000) WHO Manual for the Standardized Investigation and Diagnosis of the Infertile Couple. Cambridge University Press, Cambridge.

[24] Deka, P.K. and Sarma, S. (2010) Psychological Aspects of Infertility. British Journal of Medical Practitioners, 3, a336.

[25] Polis, C.B., Carie, C.M., Tunçalp, Ö., McLain, A.C. and Thoma, M.E. (2017) Estimating Infertility Prevalence in Low-to-Middle-Income Countries: An Application of a Current Duration Approach to Demographic and Health Survey Data. Human Reproduction, 32, 1064-1074. https://doi.org/10.1093/humrep/dex025

[26] Kjaergaard, N., Kristensen, B., Hansen, E.S., Farholt, S., Schønheyder, H.C., Uldbjerg, N. and Madsen, H. (1997) Microbiology of Semen Specimens from Males Attending a Fertility Clinic. APMIS, 105, 566-570. https://doi.org/10.1111/j.1699-0463.1997.tb05054.x

[27] Diallo, M.S., Diallo, A.S., Fotso, P., Diallo, Y., Diao, B. and Faye, O. (2015) Semen Abnormality Patterns and Parameters in Male Partners of Infertile Couples in Dakar (Senegal). Open Journal of Urology, 5, 155-160. https://doi.org/10.4236/oju.2015.59024

[28] Jarvi, K. and Noss, M.B. (1994) Pyospermia and Male Infertility. The Canadian Journal of Urology, 1, 25-30.

[29] Khan, M.S., Mohammad, S.H., Deepa, F. and Tahir, F. (2012) Association between Pus Cells and Semen Parameters in Infertile Pakistani Males. Sultan Qaboos University Medical Journal, 12, 479-484.

[30] Moretti, E., Capitani, S., Figura, N., Pammoli, A., Federico, M.G., Giannerini, V., et al. (2009) The Presence of Bacteria Species in Semen and Sperm Quality. Journal of Assisted Reproduction and Genetics, 26, 47-56. https://doi.org/10.1007/s10815-008-9283-5

[31] Grassme, H., Jendrossek, V. and Gulbins, E. (2001) Molecular Mechanisms of Bacteria Induced Apoptosis. Apoptosis, 6, 441-445. https://doi.org/10.1023/A:1012485506972

[32] Ajayi, A.B., Afolabi, B.M., Ajayi, V.D., Oyetunji, I., Biobaku, O. and Atiba, A. (2018) Men without Sperms. Open Journal of Urology, 8, 25-42.

https://doi.org/10.4236/oju.2018.81004 